\title{
HISTÓRIA E CULTURA AFRO-BRASILEIRA E INDÍGENA NAS ESCOLAS: UMA REFLEXÃO NECESSÁRIA
}

\author{
Anselmo Alencar Colares \\ UFOPA \\ anselmo.colares@hotmail.com \\ Marco Antonio de Oliveira Gomes \\ UNIR \\ marcooliveiragomes@yahoo.com.br \\ Maria Lília Imbiriba Sousa Colares \\ UFOPA \\ lilia.colares@hotmail.com.
}

\section{RESUMO:}

Diante da vigência da Lei 11.645/08 que prevê a obrigatoriedade da temática "História e Cultura Afro-Brasileira e Indígena" nas escolas, acreditamos que se faz necessário a reflexão permanente sobre seus propósitos, alcances e limites, especialmente levando-se em conta a forma como as temáticas abrangidas pela Lei são contempladas nos currículos dos cursos que formam os professores incumbidos de aplicá-la. Dessa forma, ao escrevermos este artigo objetivamos analisar historicamente o sentido da inclusão dessa temática nas salas de aula, em uma sociedade na qual os segmentos economicamente dominantes naturalizam as diferenças entre as classes sociais. Sendo a educação escolar um reflexo, em última instância, das correlações de forças existentes em uma dada sociedade, ela própria reflete os valores dominantes, bem como as suas contradições. Daí porque, pode servir tanto para a legitimidade das diferenças quanto para o desenvolvimento de propostas com vistas a superação dos mecanismos opressores que geram as desigualdades.

Palavras Chave: Educação Escolar, diversidade cultural, exclusão, inclusão.

\section{HISTORY AND AFRO-BRAZILIAN AND INDIGENOUS CULTURES IN THE SCHOOLS: A NECESSARY REFLETION}

\begin{abstract}
:
Thinking of the new law which decrees' the obligation of "History and Afro-Brazilian and Indigenous cultures " in our schools, we believe that it is necessary a constant reflection on its proposals, reach and limits, especially taking into account the way the themes reached by the law are considered in the curricula of courses designed to prepare teachers. Therefore, in this article we aim at analyzing, historically, the meaning of inclusion of this theme in the classroom, in a society in which the economically superior class dominates and naturalize the differences between the classes. As education is a reflection of the existing power in a society, it also reflects the dominating values as well as its contradictions. In this way, education can both help to legitimize the differences or help to develop the overcoming of the oppressing instruments which generate inequality.

Keywords: School Education, Cultural Diversity, Exclusion, Inclusion.
\end{abstract}


Em 10 de março de 2008, a Lei 11.645/08 alterou dispositivos da LDB tornando obrigatório a temática "História e Cultura Afro-Brasileira e Indígena" nas escolas. No entanto, é importante levantarmos as seguintes questões: a referida Lei é garantia do trabalho não estereotipado da História e Cultura Afro-Brasileira e Indígena? Como as temáticas da escravidão e da segregação do negro e do indígena são abordados nas escolas? É possível relacionar a "História e Cultura Afro-Brasileira e Indígena" e sua segregação com o desenvolvimento do capitalismo?

Não obstante a preocupação de diferentes educadores comprometidos com o reconhecimento da multiplicidade de manifestações e identidades presentes no interior da escola, e do desvelamento das condições históricas em que se constituíram as diferenças entre classes e os preconceitos étnico-raciais, as práticas pedagógicas desenvolvidas no contexto escolar ainda permanecem alicerçadas em práticas que ocultam ou desvalorizam as manifestações culturais dos segmentos marginalizados ou minoritários.

Esta verificação decorre de uma visão pouco otimista a respeito do papel preenchido pela educação escolar em uma sociedade dividida em classes sociais. Não temos dúvidas de que podemos pensar na escola como uma instituição que pode contribuir para a transformação social. No entanto, também não podemos acreditar pura e simplesmente que a escola pode tudo transformar. Se quisermos uma escola que seja uma trincheira dos trabalhadores na luta contra o capital, necessitamos fomentar transformações no interior da escola que temos. É nesse sentido que precisamos modificar a escola que nega aos trabalhadores, no conteúdo e na forma, os conhecimentos historicamente construídos, e ao mesmo tempo, naturaliza as desigualdades econômicas e raciais.

Por isso, a Lei 11.645/08, embora necessária, não implica necessariamente em uma mudança significativa nas práticas educativas no âmbito escolar, uma vez que a Lei por si só, não altera as relações de produção socialmente estabelecidas. Por outro lado, sendo a educação escolar uma instituição inserida em um determinado contexto econômico, reflete em última instância, os valores dominantes por meio dos programas educativos, dos currículos, entre outras.

A materialização da Lei 11.645/08, em sala de aula, implica necessariamente em longos passos em que deve ser considerada a correlação de forças existentes dentro da arena social, o que implica também em políticas públicas de formação dos professores e na alteração na forma pela qual ocorre a educação escolar. É importante considerarmos que não existe uma unidade prévia que aglutine as manifestações de todos os segmentos da sociedade brasileira, principalmente se levarmos em conta que é uma sociedade dividida em classes sociais.

Por isso, é importante identificarmos as abordagens e estereótipos que desvalorizam as manifestações originárias dos segmentos economicamente excluídos, entre eles os negros e os indígenas como resultado de um processo de naturalização e conservação de uma ordem baseada na apropriação privada dos meios de produção. A esse respeito, é importante salientar que a inculcação de imagens estereotipadas dos grupos marginalizados, não estão circunscritas ao espaço escolar. A título de exemplo, observemos uma reportagem da Revista Veja datada de 28 de abril de 2004:

Sem fé, lei ou rei: A Funai fez das reservas indígenas áreas de preservação de sua própria burocracia e agora enfrenta acusações de corrupção. Com o primitivismo característico do homem europeu culto e nobre do século XVI, o cronista português Pero de Magalhães Gândavo diagnosticou o que a seu ver seria a mácula original do caráter do silvícola brasileiro. Depois de uma viagem ao Brasil em 1570, ele escreveu que os índios não podiam ser mesmo grande coisa, pois na língua deles "não se acham $\mathrm{F}$, nem $\mathrm{L}$, nem $\mathrm{R}$, coisa digna de espanto, porque assim não têm Fé, nem Lei, nem Rei". A confusão mental 
de Gândavo, que não via ordem ou justiça possíveis em uma sociedade estranha se ela não reproduzisse fielmente os vocábulos de seu próprio idioma, não difere muito da imagem que seus contemporâneos tiveram dos índios. Cinco séculos depois, essa imagem praticamente se inverteu. Os índios são idolatrados. No Brasil do século XXI, todo dia é dia de índio. Os selvagens são vistos como defensores da floresta e guardiães de culturas e línguas que precisam ser preservadas a todo custo. (grifos nossos)

A edição da revista Veja de 28 de abril traz um discurso que beira ao xenofobismo e intolerância. A matéria "Sem fé, lei ou rei" trata do conflito entre índios Cinta-larga e garimpeiros no interior do Estado de Rondônia. Como se percebe ao longo do texto, a expressão selvagem não difere daquela defendida pelos colonizadores europeus ${ }^{1}$. No entanto, longe de ser uma manifestação isolada, a posição do periódico é reflexo do posicionamento político de segmentos dominantes em uma sociedade divida em classes sociais antagônicas.

É nesse sentido, portanto, que enxergamos a escola como uma instituição não isolada da sociedade. Ela reflete como qualquer instutição os conflitos presentes na arena social, bem como, é o resultado, sempre provisório, da forma como se organizou a educação e de suas vinculações históricas às formas de organização da produção material. Assim, a escola constitui-se em um espaço privilegiado para a difusão de valores, incluindo o racismo, através de um conteúdo eurocêntrico. A reiteração de abordagens e estereótipos que desvalorizam negros, índios e, fundamentalmente, os excluídos economicamente, independente de suas origens étnicas ou culturais, resultam na naturalização e conservação de uma ordem baseada numa suposta igualdade de oportunidades, cabendo a cada segmento, papéis e destinos diferentes, segundo princípios de uma suposta meritocracia.

Contudo, cabe enfatizar que as desigualdades atuais entre os chamados grupos étnicos não são consequiências de um legado biológico, mas produtos de circunstâncias materiais construídas historicamente e de conjunturas contemporâneas econômicas, educacionais e políticas.

\section{Negros e índios na América portuguesa.}

O fato é que, na América portuguesa (e consequentemente no Brasil que se constituía após a independência), não houve lugar para o negro e o índio. Não faltaram justificativas para a escravidão de ambos. Ainda que hoje, muitos condenem tal prática, quando os meios de comunicação divulgam a existência de trabalhos forçados ou em condições subumanas, é forçoso reconhecer que nem sempre foi assim o comportamento social.

É inegável a contribuição do habitante nativo para a concretização dos propósitos colonizadores, embora tenha sido numericamente mais presente a mão-de-obra africana. $\mathrm{Na}$ verdade, a maior utilização do braço africano na economia colonial, deve-se principalmente ao tráfico negreiro, atividade altamente lucrativa ${ }^{2}$, tornando-se uma das principais fontes de acumulação de capitais para a metrópole. Nesse cenário, devemos considerar também a resitência marcante de diferentes grupos indígenas, que se tornaram uma ameaça perigosa para muitos senhores de engenho. Diferentes grupos nativos reagiram de diversas formas, ocorrendo fugas, intensificando o consumo de bebidas alcoólicas e casos de homicídios como forma de reação à violência estabelecida pelo colonizador, o que comprometia a organização da economia naquele período. Cabe ainda ressaltar a defesa dos jesuítas, que voltados para catequese do índio, condenavam à sua escravidão. 
Não podemos negar que muitos colonos escravizaram pura e simplesmente diferentes comunidades. Alguns criaram campesinatos indígenas por meio da aculturação e destribalização, prática utilizada pioneiramente pelos jesuítas, e posteriormente por outras ordens religiosas. De qualquer modo, como afirmou Pablo Neruda: "A espada, a cruz e a fome iam dizimando a família selvagem”. De fato, naquele momento, a expansão do negócio do açúcar não desprezou a utilização da força de trabalho indígena.

A escravidão foi uma decorrência da política mercantilista colonial, do apoio ideológico prestado pela Igreja romana e da atividade econômica dos comerciantes negreiros. Em outras palavras, a grande propriedade monocultora exigia uma mão-deobra permanente. Era inviável do ponto de vista colonial e mercantilista a utilização de colonos assalariados, já que a intenção não era vir para trabalhar, e sim para acumular riquezas no "novo continente". O sistema capitalista embrionário e expansionista não tinha como pagar salários para milhares de trabalhadores, além do mais, a população portuguesa que não chegava aos 3 milhões, portanto reduzida para oferecer trabalhadores assalariados em grande quantidade.

Em uma sociedade patriarcal que surgiu da expansão mercantil, os colonos não mediram esforços para brutalizar negros e índios. Ainda que alguns letrados que estiveram presentes na América portuguesa, em especial os clérigos, a partir da segunda metade do século XVII, exortassem aos senhores de escravos para que dispensassem um tratamento mais "humanizado e cristão", os castigos corporais eram comuns e permitidos por lei. Vejamos as palavras de Antonil, em Cultura e opulência do Brasil, quando dirigia-se aos senhores de engenho da colônia:

E se o castigo for freqüente e excessivo, ou se irão embora, fugindo para o mato, ou se matarão por si, como costumam, tomando a respiração ou enforcando-se, ou procurarão tirar a vida aos que lhe dão tão má, recorrendo se for necessário a artes diabólicas, ou clamarão de tal sorte a Deus, que os ouvirá e fará aos senhores o que já fez aos egípcios, quando avexavam com extraordinário trabalho aos hebreus, mandando as pragas terríveis contra suas fazendas e filhos. (ANTONIL, 2007, p. 102)

Como se percebe, a postura da Igreja enquanto instituição foi de defesa da escravidão, já que ela favorecia a classe social da qual o clero se originava, a camada dos senhores de terras e homens que mantinha o clero.

À maioria dos negros ficou reservado o papel subalterno nas relações sociais, o que não significa a ausência de resistências e lutas. A propósito da resistência do negro, Frei Vicente fornece um relato bem significativo. O trecho abaixo narra os conflitos entre a burocracia administrativa metropolitana e a formação de quilombos que começavam a surgir:

[...] informado o governador que um mocambo ou magote de negros de Guiné fugidos que estavam nos palmares do rio Itapucuru, quatro léguas do rio Real para cá, mandou lhes que fossem de caminho dar neles, e os apanhassem às mãos, como fizeram, que não foi pequeno bem tirar dali aquela ladroeira e colheita que ia em grande crescimento. (SALVADOR, 1975, p. 288)

$\mathrm{Na}$ verdade, colonos e clérigos compartilhavam da idéia segundo a qual possuir escravos era algo necessário e natural. Nem mesmo as transformações econômicas geradas no interior das chamadas Revoluções Burguesas (com ênfase para a Revolução Industrial) 
e os acontecimentos que culminaram com a fuga da Família Real para o Brasil e, posteriormente, o nosso processo de emancipação, foram suficientes para romper com os vícios herdados do período colonial. A longa tradição colonial portuguesa (1500-1822) deixou grandes cicatrizes em nossa sociedade. Desnecessário afirmar que o passado colonial e as relações materiais que permaneceram forjaram a educação no Brasil imperial, a qual como privilégio de poucos.

A escravidão permaneceu intacta. Nos debates travados por ocasião da Constituinte de 1823, o tema esteve praticamente ausente, bem como a defesa dos diferentes grupos indígenas. Dessa forma, negros, índios e pobres continuaram excluídos não apenas economicamente, mas também do exercício da participação política.

As revoltas dos escravos em diferentes espaços geográficos, evidenciaram ações individuais e coletivas que contribuíram para o questionamento do cativeiro. Cabe ressaltar também que a participação de negros na Guerra do Paraguai e as pressões externas contribuíram para o processo de abolição, que apesar dos fatos citados, foi "lenta e gradual". Na verdade, a crise da escravidão foi inaugurada pela pressão inglesa que atendia aos interesses da nascente indústria desejosa em ampliar mercados. A "Bill Aberdeen", de 1845 , foi a materialização concreta dos interesses ingleses em findar com o tráfico, pois concedia direitos à Marinha britânica de aprisionar navios negreiros. O fim do tráfico, através da Lei Eusébio de Queirós, em 1850, inviabilizou economicamente a escravidão, ainda que setores significativos das elites, a priori, se posicionassem contra a libertação dos escravos.

Não por acaso, ganha espaço nesse momento a chamada "política de embranquecimento" entre amplos segmentos das elites econômicas do Império, gerada por ideologias e pelos estereótipos de inferioridade do negro, que precedida pela necessidade de braços para a lavoura contribuíra para o incremento de políticas que visaram trazer imigrantes europeus para o Brasil. Na medida que tornava-se economicamente inviável, a escravidão foi perdendo força entre os representantes das oligarquias rurais. A abolição proclamada em 1888, pouco mudou para os negros escravizados. O Império e, logo a seguir, a República recém proclamada, negou-lhes o acesso à terra para viver ou cultivar. A educação bem como uma legislação de proteção ao trabalho eram praticamente ausentes em nosso território. O que não faltou foi a repressão, dirigida contra todos os segmentos excluídos economicamente.

\section{O liberalismo e a República}

Diante das transformações ocorridas ao longo do Segundo Reinado, o regime imperial apresentava-se ineficiente do ponto de vista dos novos segmentos que aspiravam ao poder. O fim do Império e a Proclamação da República não representaram uma ruptura com as antigas estruturas de produção herdadas do passado. Sem negar as mudanças ocorridas, o que notamos desde o princípio do período Imperial até o início do século XX, é que o cenário político no Brasil vivenciou experiências que oscilaram entre a proclamação dos princípios liberais e o conservadorismo monárquico. Na verdade, tratavase de um falso embaraço entre liberalismo e conservadorismo. Para compreender a aproximação das manifestações liberais com a prática conservadora é preciso entender que, para as elites, em que pesem as divergências internas, tratava-se de manter intactos os dois principais pilares herdados do passado colonial: a escravidão e o latifúndio. A respeito do tema, Alfredo Bosi teceu as seguintes considerações:

[...] Os nossos patriotas ilustrados cumpriram a missão de cortar o fio umbilical também na esfera jurídico-política. Sob a hegemonia dos moderados e, depois, dos regressistas, o liberalismo pós-colonial deitou 
raízes nas práticas reprodutoras e autodefensivas daqueles mesmos colonos, enfim emancipados. O seu movimento conservou as franquias obtidas na fase inicial, antilusitana, do processo, mas jamais pretendeu estendê-las ou reparti-las generosamente com os grupos subalternos. $\mathrm{O}$ nosso liberalismo esteve assim apenas à altura do nosso contexto. [...]

A pergunta de fundo é então: o que pôde, estruturalmente, denotar o nome liberal, quando usado pela classe proprietária no período de formação do novo Estado?

Uma análise semântico-histórica aponta para quatro significados do termo, os quais vêm isolados ou variamente combinados:

1) Liberal, para a nossa classe dominante até os meados do século XIX, pôde significar conservador das liberdades, conquistadas em 1808, de produzir, vender e comprar.

2) Liberal pôde, então significar conservador da liberdade, alcançada em 1822, de representar-se politicamente: ou, em outros termos, ter o direito de eleger e de ser eleito na categoria de cidadão qualificado.

3) Liberal pôde, então, significar conservador da liberdade (recebida como instituto colonial e relançada pela expansão agrícola) de submeter o trabalhador escravo mediante coação jurídica.

4) Liberal pôde, enfim, significar capaz de adquirir novas terras em regime de livre concorrência, ajustando assim o estatuto fundiário da Colônia ao espírito capitalista da Lei das Terras em 1850. (BOSI, 1992, p. 199-200).

Dito de outra forma, o liberalismo representou, e ainda representa, em última instância, a defesa da ordem burguesa. Acrescentaríamos que, em suas origens, o liberalismo representou a expressão da ascensão burguesa em sua luta contra o Antigo Regime europeu. E um dos grandes representantes das bandeiras liberais foi John Locke (1632-1704). Juntamente com Thomas Hobbes (1588-1679) e Rousseau (1712-1778), Locke é um dos principais representantes do jusnaturalismo ou teoria dos direitos naturais. Tal qual Hobbes, afirma que a origem do Estado está em um contrato, ou seja, os homens isolados no estado de natureza se uniram contratualmente para constituir a sociedade civil ${ }^{3}$. Em seu discurso contratualista, Locke, defende um modelo de Estado cujo objetivo central é a conservação dos "direitos naturais" inalienáveis e intocáveis. O principal deles é o direito à propriedade privada. No entanto, na defesa de sua propriedade, o homem pode recorrer ao Estado. E em caso de omissão desse, está justificado o direito de insurreição. Ao sustentar a idéia do "contrato social", que corresponderia à passagem do estado de natureza para as sociedades organizadas, Locke justificava a monarquia limitada e, ao mesmo tempo, dissimulava suas origens com um discurso de caráter universal. Frise-se aí o elitismo presente na raiz do pensamento liberal, já que a igualdade defendida é de natureza abstrata e puramente formal: não há igualdade real, quando só os proprietários têm plenos direitos.

Descontadas algumas diferenças com o liberalismo originário do "velho continente", salta à vista do observador atento que a penetração da ideologia liberal em nossas terras foi filtrada pelos interesses econômicos das elites proprietárias. Porém, cabe ressaltar que nem mesmo Adam Smith (1723-1790) ${ }^{4}$, que proclamou a superioridade do trabalho assalariado, condenou de forma categórica o trabalho escravo nas colônias. $\mathrm{O}$ discurso em nome da liberdade excluía, e ainda exclui, a contestação dos pressupostos 
materiais da ordem estabelecida. Portanto, a elite proprietária brasileira não estava tão distante dos propósitos do liberalismo clássico.

Neste cenário conservador-liberal, o fim do Império e a Proclamação da República não representaram o rompimento com as formas de dominação de classes. As grandes propriedades continuavam imperando tanto no litoral como no interior do país. Necessidades mínimas estavam longe de serem atendidas. A adoção do regime republicano significou um projeto conservador sob a hegemonia de novos setores das oligarquias emergentes. É bem verdade que o advento da República eliminou as eleições censitárias, fortaleceu o federalismo e eliminou o Poder Moderador, mas as condições materiais de amplas camadas dos setores populares não permitiam a transformação da democracia abstrata em uma democracia concreta. Em suma: o regime instituído com a República era oligárquico, antidemocrático, e afastado dos interesses populares.

A situação de miséria e abandono das camadas de trabalhadores do campo e da cidade foi uma das características marcantes da chamada "República Velha". A exploração material dos trabalhadores no Brasil - o que não se constituía em uma novidade para o modo de produção capitalista - fundamentava-se na ordem econômica: a quantidade de trabalhadores disponíveis no "mercado livre". As leis abstratas da livre concorrência constituíam-se em mais um instrumento ideológico que mascarava a realidade concreta. Inexistia qualquer resquício de estabilidade no emprego: o crescimento do exército industrial de reserva efetivou-se graças ao grande número de imigrantes, além das crises periódicas ocorridas na produção cafeeira e a mecanização relativamente rápida das indústrias instaladas no Brasil.

Diante da configuração política e social, as revoltas na área rural, mesmo que destituídas de um projeto político transformador, foram uma constante. Os movimentos de Canudos, Contestado e o próprio Cangaço são exemplos da insatisfação presente entre os trabalhadores do campo. Por outro lado, as áreas urbanas também foram palco das manifestações da insatisfação popular, sobretudo o movimento operário. A manutenção do Estado oligárquico com a proclamação da República e as transformações ocorridas no âmbito da produção potencializaram os conflitos de classe.

Dentro de um cenário marcado pela grande crise do sistema capitalista mundial (anos 1920), caracterizado pelo questionamento da ordem liberal e pela ascensão do fascismo na Europa, a Revolução de 1930 abriu caminho para a modernização do Estado brasileiro, na medida em que destruiu as estruturas arcaicas e esgotadas da República Velha, permitindo ou sendo obrigado a aceitar a participação política de setores sociais até então afastados dos centros de decisão. Nesse sentido, os anos 20 foram extremamente turbulentos do ponto de vista político-social. Ao autoritarismo governamental corresponderam várias insurreições, surgindo novas propostas, novas idéias.

Três revoluções tiveram assim no ano de 1922 seu marco inicial: a revolução política, com o início do movimento tenentista que culminou com a "Revolução de 1930"; a revolução literária, representada pela "Semana de Arte Moderna", no mês de fevereiro, em São Paulo; e a revolução espiritual, desencadeada pelo Centro D. Vital. Lembremos ainda que neste mesmo ano foi fundado o Partido Comunista do Brasil. (DIAS, 1996, p.89-90)

É nesse sentido que se considera 1922 um ano simbólico: foi fundado o Partido Comunista, em boa parte oriundo do anarco-sindicalismo e empenhado em defender o socialismo; surge o tenentismo, movimento civil e militar orientado no sentido de alterar 
as estruturas oligárquicas prevalecentes; ocorre a Semana de Arte Moderna em São Paulo, procurando novos temas e novas linguagens para as artes e o pensamento social no país; foram criados o Centro D. Vital e sua revista A Ordem, congregando católicos interessados em preservar a "civilização cristã" no país. Os acontecimentos de 1922 parecem sugerir prenúncios de uma nova época. O crescimento da classe operária e a insatisfação das classes médias são outras marcas dos anos 20.

Sem dúvida, é o momento de questionamento do Estado oligárquico e do surgimento de novos atores sociais. O modernismo elaborou uma alternativa simbólica para a questão da nacionalidade. Na virada dos anos 20 para os anos 30, o discurso dos segmentos emergentes com relação à brasileiros de origem negra passou a ser demarcada por três construções simbólicas: a compreensão da escravidão como um elemento opressor, em oposição às justificativas utilizadas no passado colonial; o reconhecimento das contribuições culturais dos negros e índios na formação cultural do "povo" brasileiro, tema presente na obra de Gilberto Freyre; e finalmente a idéia de que enquanto "povo", o homem brasileiro seria originário da "mistura" entre colonos europeus, negros e índios.

No entanto, o novo discurso não implicou na inclusão econômica daqueles segmentos da população. Negros e índios foram apenas apropriados como marcos simbólicos instituidores de uma civilização brasileira. Não obstante algumas exceções, permaneceram excluídos do âmbito político e econômico. Desta forma, o racismo moderno constituiu-se em mais um instrumento de hegemonia de uma classe sobre outra, dentro das relações de produção da vida material então estabelecidas Cabe ressaltar as palavras de Alfredo Bosi:

As camadas mais pobres da população brasileira [...] foram colonizadas pela cultura rústica ou, eventualmente, urbana dos portugueses, e pelo catolicismo ritualizado dos jesuítas; e agora, já em plena mestiçagem e em plena sociedade de classes capitalistas, estão sendo recolonizadas pelo Estado, pela Escola Primária, pelo Exército, pela indústria cultural e por todas as agências de aculturação que saem do centro e atingem a periferia. [...] Até onde as imagens, as idéias e os valores dessas agências culturais estarão penetrando no imaginário e condicionando o sistema de valores do povo? (BOSI,1992, p. 336). (grifos nossos)

Sem dúvida, a julgar pelo posicionamento da Revista Veja, reproduzido anteriormente, e que não é exclusividade deste periódico, confirma-se a continuidade daquilo que Bosi diagnosticou com extrema lucidez.

\section{O Movimento escolanovista e a educação.}

Aqui, tornam-se necessárias algumas palavras a respeito das propostas liberais presentes no âmbito da educação na década de 1920, que refletia as transformações econômicas que ocorriam na arena social e, possibilitava, ao mesmo tempo, o surgimento de novos interesses que conflitaram com os das oligarquias dominantes. Em um cenário marcado pelo crescimento do interesse sobre o tema da educação, Nagle (1974), diagnosticou como uma das características dos anos 20 o "otimismo pedagógico" e o "entusiasmo pela educação", uma vez que surgem os "educadores profissionais", isto é, intelectuais voltados especificamente para o tema educacional, e que se empenharam em debates e planos de reforma com a finalidade de recuperar o atraso educacional brasileiro. Nesse contexto, a Associação Brasileira de Educação (ABE) fundada por Heitor Lira, em 1924, constituiu-se em um grande fórum dedicado aos debates, cursos, conferências sobre 
temas educacionais, políticos e sociais do qual participavam professores e eminentes intelectuais. As Conferências Nacionais de Educação constituíram-se no principal instrumento de difusão dos propósitos da ABE. Muitas idéias surgidas durante os debates foram levadas adiante através das reformas estaduais e, depois, de 1930, através do próprio Governo Federal ${ }^{5}$.

Nesse cenário, emerge o movimento da Escola Nova, introduzida no Brasil no final da década de vinte, pelos "Pioneiros da Educação Nova", o qual tinha na escola pública, laica, universal e gratuita sua grande bandeira ${ }^{6}$. Embora esposando concepções políticas heterogêneas, os intelectuais ligados ao movimento tinham como pressuposto comum a crítica à escola existente, uma vez que esta se caracterizava pela seletividade social do grupo ao qual se dirigia, além de significar uma educação de caráter formalista. Para os renovadores, a educação seria um instrumento de democratização das relações sociais, na medida em que neutralizaria as desigualdades econômicas e que proporcionaria a todos a mesma formação. Nesse raciocínio, a educação laica voltada para o desenvolvimento da ciência e condizente com a industrialização seria a solução para os grandes problemas contemporâneos, além de significar a possibilidade do desenvolvimento econômico e da democratização das relações sociais.

Esse posicionamento político, típico do liberalismo burguês, alicerçava-se na crença em um Estado "neutro", além de uma concepção não ideológica da ciência e da técnica, o que não passa de um idealismo em uma sociedade dividida em classes antagônicas. Na verdade, ao transformar a educação no único e grave problema do Brasil, pois sua deficiência seria o motivo de nosso atraso, o discurso dos renovadores colaborava para a ocultação das origens materiais das desigualdades sociais.

Sob a hegemonia dos intelectuais comprometidos com a ideologia liberal, defensores de uma educação pública mantida pelo Estado ou não, com as reformas que se seguiram na chamada Era Vargas até a promulgação da Lei de Diretrizes e Bases da Educação Nacional (LDB) $n^{\circ}$ 4.024, de 20 de Dezembro de 1961, não romperam com inúmeros vícios do passado. A dualidade "criticada" por muitos reformadores foi mantida em um claro movimento de conciliação de interesses, que já se manifestava antes mesmo da promulgação de nossa primeira LDB. Vejamos o pronunciamento de Anísio Teixeira:

\footnotetext{
Não advogamos o monopólio da educação pelo Estado, mas julgamos que todos tem direito à educação pública, e somente os que quiserem é que poderão procurar a educação privada. (...) Na escola pública, como sucede no exército, desaparecerão as diferenças de classe e nela todos os brasileiros se encontrarão, para uma formação comum, sem os preconceitos contra certas formas de trabalho essenciais à democracia. (TEXEIRA, 1999, p. 101) (grifos nossos)
}

O trecho reproduzido acima caracteriza bem o discurso que ainda hoje se encontra presente nos círculos liberais. Trata-se de uma análise que concede à escola o poder quase mágico de transformar a realidade. Porém, o fato é que, em nosso entendimento, a escola não é capaz de eliminar por si só todas as questões relativas à desigualdade gerada pela barbárie capitalista. É de se ressaltar que, embora os expoentes do liberalismo comemorem o crescimento nas taxas de escolarização de base, o acesso ao saber não foi equitativo, e nem o será no âmbito de uma sociedade dividida em classes antagônicas. Em nosso entendimento, não se pode falar em educação escolar em uma sociedade divida em classes antagônicas senão como expressão desta divisão e, por conseguinte, no plural: escola de rico, escola de pobre; escola pública, que se confunde com as escolas mantidas pelo 
Estado, e escola privada. Dessa forma, entendemos que a dualidade escolar decorre da hierarquização da produção e seu controle pela burguesia. Em outras palavras, a marca social da educação escolar está no fato de existir um tipo de escola para cada grupo social. Vejamos os apontamentos de Lucília R. de Souza Machado sobre o tema.

Nas antigas ordens escravista e feudal era possível deixar os trabalhadores sem qualquer instrução, mas o moderno assalariado não pode deixar de receber determinados conhecimentos necessários ao desempenho de suas funções. Além disso, a nova ordem burguesa e o Estado que a representa espera dos trabalhadores, que são também cidadãos, um mínimo de instrução que lhes possibilite a compreensão de suas regras, de tal maneira que possam se responsabilizar pelos seus atos. Como, porém, o acesso à instrução é limitado e controlado por exigências técnicas e políticas, o ensino destinado aos trabalhadores tem sempre um caráter inacabado, forçado e falso. São tais contradições que impõem limites às reformas escolares da burguesia. Esta classe descobriu, bem cedo, que no âmbito da sabedoria, há sempre a possibilidade de surgimento da contestação, mas, por outro lado, não pode deixar de fornecê-la, ainda que incompleta e limitada. (MACHADO, 1989, p. 32) (grifos nossos)

Ou seja, as populações são incluídas nas escolas, mas a lógica do liberalismo presente marginaliza-as e as exclui. Não são dadas as condições financeiras e científicas de formação do professor (para a docência no sentido amplo, o que inclui a pesquisa), e de sua permanente renovação pedagógica. De outra parte, crianças e jovens não têm acesso a escolas do mesmo nível, posto que isso depende das condições materiais de seus pais. Dessa forma, aqueles que trazem em sua bagagem as carências econômicas das classes subalternas entram em situação de desvantagem no processo competitivo desenvolvido no interior da sociedade. Assim, a partir de uma desigualdade concreta, não há como falar na igualdade de oportunidades oferecidas pela educação. A promessa meritocrática faliu, se é que existiu algum dia para todos. A escola, como toda e qualquer instituição social, está circunscrita às suas raízes históricas e a determinantes econômicos, políticos e sociais.

Nesse sentido, cabe uma questão: o pensamento conservador-liberal continua ainda presente no âmbito da educação? Em que pese a ampliação de vagas nas escolas, é inegável que as políticas educacionais seguiram a lógica das bandeiras neoliberais. Por outro lado, se atentarmos para as condições das escolas brasileiras públicas, verificaremos que permanecem precarizadas muitas ainda com professores não habilitados e uma profunda destruição do caráter público da educação.

Dessa forma, mesmo que amplos segmentos das camadas trabalhadoras ingressem na escola, o fato é que prosseguem marginalizados, pois continuam sem acesso ao conhecimento historicamente constituído e desvalorizados em suas manifestações particulares. Para termos idéia dos condicionantes materiais da reprodução da situação citada, basta atentar para as dificuldades que se apresentam, para estabelecer relações de produção do conhecimento em sala de aula: professores mal remunerados e com inúmeras aulas em sua carga horária, salas repletas de alunos, ausência de assessoramento pedagógico, formação profissional deficiente, entre outros.

Com base no exposto, consideramos que a tarefa crucial do trabalho educativo é possibilitar que os trabalhadores compreendam a conjuntura em que vivem, e assumam o papel de sujeitos do processo histórico-social. Isso significa, mais concretamente, opor-se à educação a serviço da dominação de classe em favor da educação da resistência, buscando, 
dentro de seus limites, promover a luta pela superação da ordem estabelecida. Sendo assim, para além de uma escola centrada na forma e não no conteúdo, é necessário romper com a educação mistificadora, buscando criar condições materiais para que todos tenham acesso ao conhecimento historicamente produzido.

A armadilha pós-moderna e os limites do discurso sobre a valorização da diversidade.

Ellen Wood, ao refletir sobre o discurso das chamadas políticas de identidade, sintetiza o desenho de pensamento que se tornou comum em um leque significativo das correntes de esquerda. A autora elucida que, hoje em dia, muitos militantes de tal corrente esposam a tese que o mundo contemporâneo caracteriza-se pela fragmentação e diversificação das relações sociais, pela pluralidade de identidades; muitos inclusive afirmando que vivenciamos uma era "pós-moderna", no qual o conceito de classes sociais perdeu o significado diante de outras formas de opressão. Essas representações da sociedade contemporânea, segundo a autora, e com a qual concordamos, fazem parte de uma amplo arco de pensamentos que configuram aquilo que se convencionou chamar de "agenda pós-moderna" (WOOD, 1999, p. 17).

De um lado, não negamos a existência de manifestações culturais múltiplas que são negadas ou esvaziadas pelo discurso dominante. Porém, antes das divisões étnicas, e culturais, que sem dúvida devem ser levadas em conta, existe a divisão de classes. A vida dos negros nas periferias das grandes metrópoles pode ser tão miserável quanto aos dos camponeses, independente de sua origem étnica. Em outras palavras, a vida de todos os grupos sociais e culturais são afetadas, antes e essencialmente, pelas relações capitalistas de produção.

Essa perspectiva não pretende em momento algum negar o racismo historicamente construído através das relações materiais entre os homens, mas alertar para o fato de que qualquer perspectiva que parta do ponto de vista dos trabalhadores deve desvelar a dimensão política e econômica da exclusão das diferentes identidades, que em última instância são excluídas fundamentalmente pelo critério de classes sociais dentro de uma dada realidade histórica.

\section{A nova configuração do mundo do trabalho e a agenda pós moderna}

A crise do liberalismo econômico no final dos anos 20 do século anterior inaugurou o chamado keynesianismo que se consolidou de fato, após a Segunda Guerra Mundial. Eram os "anos de ouro do capitalismo", que diga-se de passagem, não foram tão reluzentes para todos. O crescimento acelerado no pós guerra entrou em uma fase crítica, sobretudo no início da década de 1970. A crise do Petróleo, combinada com a redução do crescimento econômico e aceleração inflacionária, contribuiu para a ascensão da ideologia neoliberal.

O colapso no padrão de acumulação do modelo fordista/taylorista levou o capital a procurar estratégias de recuperação das taxas de lucro através das propostas neoliberais, que enxergavam no Estado, e em suas políticas sociais, o grande vilão da economia. Os intelectuais identificados com o discurso neoliberal declaravam que as despesas do Estado com políticas públicas e o poder dos sindicatos destruíam os níveis necessários de lucro das empresas.

Assim sendo, como tentativa de gerenciar a sua crise estrutural, foi iniciado o processo de reestruturação do capital e de seu sistema jurídico e ideológico de dominação. A solução estaria no chamado "Estado-mínimo" para as questões sociais, mas forte o suficiente para controlar os gastos públicos e enfraquecer os sindicatos, ao mesmo tempo 
que buscava-se a desregulamentação dos direitos trabalhistas, além da desmontagem do setor produtivo estatal.

No ponto de vista neoliberal, a estabilidade monetária deveria ser o objetivo principal de qualquer governo. Assim, a realização de reformas fiscais, entendida como redução dos impostos sobre o capital, era condição fundamental para incentivar a retomada econômica. A alternativa do capitalismo para sua crise estrutural acarretou um processo de substituição do modelo industrial fordista/taylorista e do modelo político-econômico Keynesiano pelo regime de acumulação flexível, fortalecendo em grande parte o capital financeiro e especulativo em um contexto de desmoronamento das experiências do chamado "socialismo real", que sem dúvida, auxiliou na difusão - entre muitos intelectuais - da idéia de que o liberalismo e a economia de mercado venceram em termos absolutos, e teriam se transformado em modelo permanente e categórico de organização da vida humana

Nesse cenário, o "pós-modernismo" configurou-se em uma expressão ideológica das transformações que ocorreram no âmbito da produção. Configura-se, segundo Wood (1999, p. 18), de determinadas balizas que formam um rol de bandeiras, a qual é composta por uma vasta gama de tendências intelectuais e políticas que surgiram em anos recentes.

Pelo menos num aspecto, todos os pós-modernos aderem: vivemos uma crise de paradigmas. Circunstância em que o conhecimento é sistematicamente colocado a prova, ao mesmo tempo em que se afirma o relativismo das verdades historicamente construídas pela Modernidade. Dessa forma, a agenda "pós-moderna" questiona as noções clássicas de razão, verdade, objetividade, o conceito de progresso ou emancipação universal e as grandes narrativas. Além disso, poderíamos identificar como temas recorrentes ao discurso "pós-moderno" a atitude cética em relação ao marxismo e à possibilidade de o capitalismo ser superado por uma sociedade que lhe seja superior. Em oposição aos pilares do pensamento iluminista, compreende o mundo como imprevisível e instável, com um grande grau de ceticismo em relação às explicações universais.

Esses pontos, entre outros, que compõem o pensamento pós-moderno significaram a consolidação no âmbito da ideologia dos interesses burgueses, na medida em que nega a possibilidade de conhecimento objetivo e a superação da ordem social existente, substituindo a luta de classes pela lógica do contentamento das diferentes identidades que compõem o mosaico social. Por isso, em nosso entendimento, o tema da diversidade cultural foi encampado pelos pós-modernistas, uma vez que se colocam em defesa das minorias, todavia, negando o conceito de classes. Em outras palavras, por representar o movimento ideológico da nova fase de acumulação do capital, o discurso pós-moderno relega à categoria de mitos eurocêntricos totalitários os postulados que fundaram e orientaram a modernidade: as idéias de racionalidade e universalidade, privilegiando assim, a subjetividade fragmentada e dilacerada.

Cabe enfatizar que, além das transformações no âmbito da produção, colaboraram para a ofensiva ideológica pós-moderna as experiências dos regimes totalitários, entendidos não como produto de relações econômicas marcadas pelo ímpeto imperialista, mas como conseqüência da "modernidade". Descrentes com o curso da história e sem perspectivas de mudanças sociais, uma vez que o chamado socialismo real apresentava sinais de desgaste, intelectuais pós-modernos afirmaram a primazia da diversidade sobre a igualdade.

Neste ponto reside aquilo que entendemos ser uma das contradições das bandeiras pós-modernas: aceita como inevitável a ordem estabelecida, ou pelo menos, não oferece alternativas razoáveis, mas rejeita os projetos alicerçados na razão, responsabilizando-os pelos barbárie que deve ser creditada ao próprio capitalismo. 


\section{Diversidade cultural, inclusão e educação: limites e possibilidades}

Em nosso entendimento, não é possível analisar tudo apenas em termos de cultura, o que não significa negar as denúncias das discriminações que ocorreram, e ainda ocorrem em nossa sociedade. Para Alfredo Bosi, a relação entre a chamada cultura erudita e a cultura popular é a que proporciona maior grau de distinção. Ou a primeira ignora as manifestações simbólicas do povo, ou as encara como um simples observador: "A cultura erudita quer sentir um arrepio diante do selvagem" (1992, p. 330) ${ }^{7}$.

No entanto, para muitos autores, o que não é o caso de Bosi, as reivindicações pelo reconhecimento cultural parecem ter sobrepujado à luta de classes e à denúncia da exploração socioeconômica que caracterizaram a sociedade capitalista como um todo. Afinal, como salientou Marx e Engels no Manifesto Comunista: "[...] em lugar da exploração velada por ilusões religiosas e políticas, a burguesia colocou uma exploração aberta, cínica, direta e brutal". Na verdade, por trás das tensões existentes entre diferentes etnias em distintas regiões do mundo, há, antes de qualquer coisa, a tensão entre os que controlam os meios de produção e aqueles que são destituídos da riqueza gerada pelo trabalho. Nesse sentido, parece-nos oportuno afirmar que o reconhecimento de uma cultura considerada minoritária não implica o fim de sua alienação socioeconômica. Por isso a pergunta: de que espécie de emancipação se trata quando são levantadas as bandeiras da diversidade cultural?

Os pós-modernistas rejeitam o universalismo iluminista alegando que ele nega a diversidade de experiências, culturas, valores e identidades humanas. Porém, essa rejeição do universalismo em nome de um pluralismo libertador é contraditória e auto-anuladora. Um respeito sadio pela diferença e a diversidade, e pela pluralidade das lutas contra os vários tipos de opressão, não nos obriga a descartar todos os valores universalistas aos quais o marxismo, em sua melhor expressão, sempre esteve ligado, ou a abandonar a idéia de emancipação humana universal. (WOOD, 1999, p. 18)

Entendemos que a emancipação política, ou ainda, a construção de uma sociedade marcada por relações entre iguais, só poderá ocorrer com a dissolução das bases econômicas das relações capitalistas de produção. Assim sendo, o grande desafio consiste em conciliar as estratégias de combate pela superação da ordem mantida pelo capital com as lutas políticas de reconhecimento das chamadas minorias. Dessa forma, não devemos nos esquecer: sob o domínio do capital o homem é transformado em mercadoria independente de suas origens étnicas ou culturais. De nada adianta reconhecermos os direitos das "minorias" se não alterarmos substancialmente as relações de produção. Por outro lado, é forçoso reconhecer que nem todos os membros das chamadas minorias são desfavorecidos do ponto de vista econômico, bem como sabemos que existem grupos da população realmente desfavorecidos que não pertencem às minorias étnicas. Neste caso, todas as diferenças podem ser defendidas?

Atualmente, muitos intelectuais se opõem ao que julgam ser uma visão etnocêntrica, calcada dominação cultural da elite branca, presente no currículo escolar, defendendo, em contrapartida, a diversidade cultural, como uma estratégia de orientação educacional para o reconhecimento das diferenças culturais na instituição escolar. No 
entanto, a grande ironia é o não reconhecimento da possibilidade de superação das desigualdades econômicas, base de todas as diferenças.

Não negamos a necessidade de valorização da história dos povos afrodescendentes, dos indígenas, ou ainda, dos aspectos regionais, mas não podemos desvinculá-los das questões macro. Afinal, quer queiramos ou não, aquilo que ocorre no âmbito das particularidades é reflexo, em última instância, do modo de produção dominante. A propósito, o Manifesto comunista (1998) é muito elucidativo:

\begin{abstract}
A grande indústria criou o mercado mundial preparado pela descoberta da América. O mercado mundial acelerou prodigiosamente o desenvolvimento do comércio, da navegação, dos meios de comunicação. Esse desenvolvimento reagiu por sua vez sobre a extensão da indústria; e à medida que a indústria, o comércio, a navegação, as vias férreas se desenvolviam, crescia a burguesia, multiplicando seus capitais e relegando a segundo plano as classes legadas pela Idade Média. Vemos pois, que a própria burguesia moderna é o produto de um longo processo de desenvolvimento, de uma série de revoluções no modo de produção e de troca. [...].
\end{abstract}

Devido ao rápido aperfeiçoamento dos instrumentos de produção e ao constante progresso dos meios de comunicação, a burguesia arrasta para a torrente de civilização mesmo as nações mais bárbaras. Os baixos preços de seus produtos são a artilharia pesada que destrói todas as muralhas da China e obriga a capitularem os bárbaros mais tenazmente hostis aos estrangeiros. Sob pena de morte, ela obriga todas as nações a adotarem o modo burguês de produção, constrange-as a abraçar o que ela chama civilização, isto é, a se tornarem burguesas. Em uma palavra, cria um mundo à sua imagem e semelhança. (grifos nossos)

Como se vê, nada mais atual, em que pese as transformações ocorridas no capitalismo desde 1848, ano da publicação do Manifesto Comunista. Por conseguinte, não há como desvincular o tráfico, a escravidão, a destruição das comunidades indígenas, a abolição da escravidão, ou mesmo a segregação econômica do negro, de um processo mais amplo: a expansão do mercado mundial sob a batuta da burguesia. Por outro lado, é evidente que o capitalismo adquiriu determinadas particularidades em diferentes pontos do mundo, mas isso não implica em negar a sua essência anti-civilizatória.

Nesse sentido, a defesa de uma educação que leve em conta as diversidades e o chamado multiculturalismo coloca a todos nós, educadores, o grande desafio de estar atentos às transformações econômicas e seus reflexos na arena social, bem como de lutar por políticas públicas de formação do educador com formação teórica sólida, que saiba analisar a realidade em que aturará, que aceite as diferenças sem aceitar as desigualdades. Assim sendo, o educador deverá conhecer os mecanismos de dominação e de transformação do homem em mercadoria. Observemos, as palavras de Olgária Matos:

Sabemos que, no Brasil, é possível freqüentar escolas durante anos sem aprender o Português e, também nas Universidades, esse "dialeto" está, aos poucos, se tornando um idioma estrangeiro, cuja sintaxe e gramática é desconhecida, dominado apenas imperfeitamente. (MATOS, 2006, p. 24) 
Se confrontarmos a promulgação da Lei 11.645/08 que tornou obrigatória a temática "História e Cultura Afro-Brasileira e Indígena" nas escolas, com as práticas de formação de professores, observamos a existência de um descompasso do país, o oficial e o oficioso, o Brasil legal e o Brasil real. Em outras palavras, a lei é promulgada, altera a LDB (Lei 9394/1996), mas é o caso de questionarmos: quantas cursos de licenciatura abordam a questão?

Por isso, entendemos que pensar em uma escola pública de qualidade requer questionar a forma como ocorre sua configuração, desde seu financiamento, passando pelos objetivos, as formas pelas quais ocorrem a formação de professores, até ao público que se destina. Para um melhor esclarecimento de caminhos didáticos possíveis para a temática em questão, faz-se urgente desenvolver práticas de questionamento do senso comum acerca das relações étnico raciais em nossa sociedade. Em nosso entendimento, a compreensão da História da escravidão do negro e do índio, bem como das formas de resistência, poderá contribuir para a luta contra a dominação de classes presentes no cenário contemporâneo. Não se trata de negar o projeto de uma ciência alicerçada em pressupostos racionalistas e universais, mas de compreender à luz da mesma ciência a historicidade da exclusão e da possibilidade de transformações, uma vez que a história não chegou ao seu "fim".

Em outras palavras, devemos nos colocar frontalmente contra as perspectivas que abordam a história das chamadas minorias de forma folclorizada e pitoresca. Afinal, a miséria, a segregação, o racismo, bem como a opulência possuem uma história. Desvelar a trama da história é da mais alta relevância para a superação das injustiças sociais. Ora, se a escola também reproduz, através dos programas oficiais, a desigualdade da sociedade capitalista, é forçoso reconhecer que ela é também um espaço de luta a ser conquistado pelos setores populares.

Se a educação no mundo contemporâneo está centrada nos valores hegemônicos das elites dominantes, isso não implica que deverá ser sempre assim. Caso contrário, negaríamos a História como ciência. Assim sendo, um longo caminho necessita ser vencido para que a escola seja um instrumento de afirmação dos trabalhadores como classe, sem descuidar de questões culturais específicas. A falta de conhecimento das características e das especificidades regionais, em um país com dimensões continentais como o nosso, bem como a desinformação quanto aos referenciais das culturas silenciadas (como os diferentes povos indígenas, negros e imigrantes) nos currículos escolares, contribuem para a consolidação de visões estereotipadas e preconceituosas.

A escola ainda é reprodutora, em grande medida, de uma perspectiva burguesa com todos os seus valores inerentes, mas também pode vir a ser transformadora, visto que pode promover uma apropriação crítica desse mesmo conhecimento burguês, tendo em vista a melhoria da qualidade de compreensão da realidade marcada pelas contradições de uma sociedade dividida em classes antagônicas.

Neste horizonte, torna-se urgente trazer para o âmbito da educação escolar a discussão sobre a história e a cultura daqueles que foram excluídos. É importante que os filhos dos trabalhadores percebam que não é só o vencedor que faz a história, mas que outros segmentos, independente de suas origens étnicas possuem história e que é preciso conhecê-la para enfrentarmos os desafios futuros.

Por fim, cabe aos intelectuais comprometidos com os segmentos populares, repensar a formação de professores em uma perspectiva que valorize a fundamentação teórica e metodológica, os conteúdos específicos de sua disciplina e suas práticas, a fim de que possa constituir o contraponto necessário para não cairmos em meras situações paliativas. 


\section{REFERÊNCIAS}

ANTONIL, André João. Cultura e Opulência do Brasil por suas drogas e minas. São Paulo: Edusp, 2007.

BOSI, Alfredo. Dialética da colonização. São Paulo: Companhia das Letras, 1992.

DIAS, Romualdo. Imagens da ordem - a doutrina católica sobre autoridade no Brasil (1992-1933). São Paulo: Editora da Universidade Estadual Paulista, 1996.

FERNANDES, Florestan. A revolução burguesa no Brasil: ensaio de interpretação sociológica. Rio de Janeiro: Guanabara, 1987.

FREIRE, Paulo. Pedagogia da autonomia: saberes necessários à prática educativa. 24. ed. São Paulo: Paz e Terra, 2002.

GRAMSCI, Antonio. Os intelectuais e a organização da cultura. 6. ed., Rio de Janeiro: Civilização Brasileira, 1988. 1988 .

Maquiavel, a política e o Estado moderno. Rio de Janeiro: Civilização Brasileira,

IANNI, Octavio. O colapso do populismo no Brasil. 4.ed., Rio de Janeiro: Civilização Brasileira, 1988.

As aventuras de Karl Marx contra o Barão de Münchausen. 5 ed. São Paulo: Cortez, 1994

JAPIASSÚ, Hilton. MARCONDES, Danilo. Dicionário básico de filosofia. Rio de Janeiro: Jorge Zahar. 1996.

MARX, Karl, ENGELS, Friedrich. Manifesto do partido comunista. São Paulo: Cortez, 1998.

MELLO, Leonel Itaussu Almeida. John Locke e o individualismo liberal. In: WEFFORT, Francisco C. Os clássicos da política. vol. I São Paulo: Ática, 1999.

MACHADO, Lucília R. de Souza. Politecnia, escola unitária e trabalho. São Paulo:

Cortez: Autores Associados, 1989.

MATOS, Olgária. Discretas esperanças: reflexões filosóficas sobre o mundo contemporâneo. São Paulo: Nova Alexandria, 2006.

MÉSZÁROS, István. O século XXI: socialismo ou barbárie? São Paulo: Boitempo Editorial, 2003.

O poder da ideologia. São Paulo: Boitempo Editorial, 2004.

A educação para além do capital. São Paulo: Boitempo Editorial, 2005.

NAGLE, Jorge. Educação e sociedade na primeira República. São Paulo: Editora Pedagógica e Universitária, 1974.

PAIVA, José Maria de. Colonização e catequese, 1549-1600. São Paulo: Autores Associados: Cortez, 1982.

SALVADOR, Frei Vicente do. História do Brasil (1500-1627). 6. ed. São Paulo: Companhia Melhoramentos; Instituto Nacional do Livro, 1975, p. 82.

SAVIANI, Dermeval. Pedagogia histórico-crítica: primeiras aproximações. Campinas: Autores Associados, 2003.

SILVA, Tomaz Tadeu. da. (org.). A produção social da identidade e da diferença. In: Identidade e diferença : a perspectiva dos estudos culturais. Petrópolis, RJ:

Vozes, 2000. cap. 2, p. 73 -102.

Sem fé, lei ou rei, Veja, 28 de abril de 2004.

TEIXEIRA, A.S. O Manifesto dos Pioneiros da educação nova. Revista Brasileira de Estudos Pedagógicos,1984, 65(150):407-425.

TEIXEIRA, A.S. Educação no Brasil. Rio de Janeiro, Editora UFRJ, 1999.

TEIXEIRA, Anísio. Educação não é privilégio. Rio de Janeiro: Ed. UFRJ, 1999. 
WOOD, Ellen Meiksins. O que é agenda pós-moderna? In: WOOD, Ellen Meiksins; FOSTER, John Bellamy (orgs.). Em defesa da história: Marxismo e pós-modernismo. Rio de Janeiro: Jorge Zahar, 1999.

Notas:

${ }^{1}$ [Os índios] não tem fé, nem lei, nem rei (...). são mui desumanos e cruéis, (...) são mui desonestos e dados à sensualidade (...). Todos comem carne humana e têm-na pela melhor iguaria de quantas pode haver (...). Vivem mui descansados, não têm cuidado de cousa alguma se não de comer e beber e matar gente. (Pero de Magalhães Gandavo. Tratado da Terra do Brasil, século XVI.)

2 "Seiscentas peças barganhei - que pechincha no Senegal/A carne é rija, os músculos de aço/ Boa liga do melhor metal/Em troca dei só aguardente, Contas, latão - um peso morto ! Eu ganho oitocentos por cento/ Se a metade chegar ao porto (Heirich Heine - Apud Alfredo Bosi _ Dialética da Colonização - 1992)

${ }^{3}$ Para Hobbes, o poder soberano deve ser absoluto, isto é, ilimitado. O legado do poder dos indivíduos ao soberano deve ser total, caso contrário, a liberdade levará novamente à guerra. É o medo e o desejo de paz que levam os homens a fundarem um estado social.

${ }^{4} \mathrm{O}$ liberalismo econômico tem em Adam Smith um de seus principais expoentes, considera que existem leis inerentes ao próprio processo econômico - tais como a da oferta e da procura - que estabelecem o equilíbrio entre a produção, a distribuição e o consumo de bens em uma sociedade. O Estado não deve intervir na economia, mas apenas garantir a livre iniciativa e a propriedade privada dos meios de produção. O liberalismo econômico defende assim a chamada "economia de mercado" (JAPIASSÚ e MARCONDES, 1996, p. 163)

${ }^{5}$ Em 1930 é criado o Ministério da Educação e Saúde, órgão para o planejamento das reformas em âmbito nacional e para a estruturação da Universidade no Brasil.

${ }^{6} \mathrm{O}$ escolanovismo foi um movimento mundial, com forte acento pedagógico. A face mais "política" do movimento deveu-se sobretudo ao norte-americano John Dewey.

Em 1932 é lançado o Manifesto dos Pioneiros da Educação Nova, encabeçado por Fernando de Azevedo e assinado por 26 educadores. O manifesto fez a defesa da educação obrigatória, pública, gratuita e leiga como um dever do Estado, a ser implantada em programa de âmbito nacional. Por outro lado, o documento criticava o dualismo educacional, que destinava uma escola para ricos e outra para pobres, reivindicando a escola básica e única, considerada ponto de partida comum para todos.

${ }^{7}$ A respeito das diferenças entre cultura popular e cultura erudita, vejamos as anotações de Alfredo Bosi: Cultura popular implica modos de viver: o alimento, o vestuário, a relação homem-mulher, a habitação, os hábitos de limpeza, as práticas de cura, as relações de parentesco, a divisão das tarefas durante a jornada e,simultaneamente, as crenças, os cantos, as danças, os jogos, a caça, a pesca,o fumo, a bebida, os provérbios, os modos de cumprimentar, as palavras tabus, os eufemismos, o modo de olhar, o modo de sentar, o modo de visitar e ser visitado, as romarias, as promessas, as festas do padroeiro, o modo de criar galinha e porco, os modos de plantar feijão, milho e mandioca, o conhecimento do tempo, o modo de rir e de chorar, de agredir e de consolar... (BOSI, 1992, p. 324).

A cultura erudita cresce principalmente nas classes altas e nos segmentos mais protegidos da classe média: ela cresce com o sistema escolar. A cultura de massa, ou indústria cultural, corta verticalmente todos os estratos da sociedade, crescendo mais significativamente no interior das classes médias. A cultura popular pertence, tradicionalmente, aos estratos mais pobres, o que não impede o fato de seu aproveitamento pela cultura de massa e pela cultura erudita, as quais podem assumir ares popularescos ou populistas em virtude de sua flexibilidade e da sua carência de raízes (1992, p. 226).

Artigo recebido em: 29/10/2009

Aprovado em: 9/3/2010 